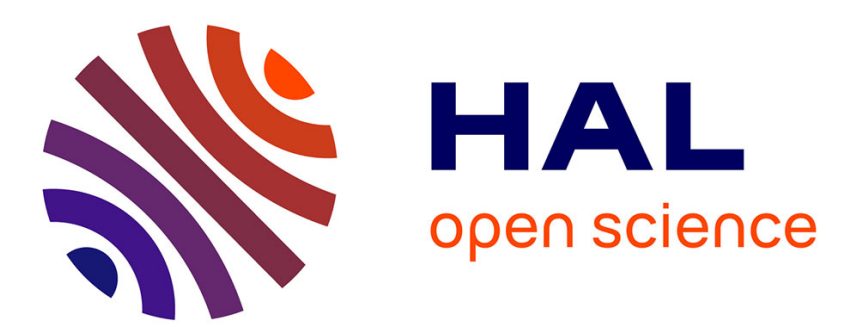

\title{
The things that go without saying. On performative differences between business value communication and communication on business values Steffen Roth
}

\section{- To cite this version:}

Steffen Roth. The things that go without saying. On performative differences between business value communication and communication on business values. International Journal of Business Performance Management, 2014, 15 (3), pp.175-191. 10.1504/IJBPM.2014.063018 . hal-01053515

\author{
HAL Id: hal-01053515 \\ https://hal.science/hal-01053515
}

Submitted on 31 Jul 2014

HAL is a multi-disciplinary open access archive for the deposit and dissemination of scientific research documents, whether they are published or not. The documents may come from teaching and research institutions in France or abroad, or from public or private research centers.
L'archive ouverte pluridisciplinaire HAL, est destinée au dépôt et à la diffusion de documents scientifiques de niveau recherche, publiés ou non, émanant des établissements d'enseignement et de recherche français ou étrangers, des laboratoires publics ou privés. 


\title{
The things that go without saying: on performative differences between business value communication and communication on business values
}

\author{
Steffen Roth \\ ESC Rennes School of Business, \\ 2 Rue Robert d'Abrissel, \\ 35000 Rennes, France \\ E-mail: steffen.roth@esc-rennes.fr
}

\begin{abstract}
This article argues that analyses of value semantics in organisational image brochures, websites, and further official documents do not give information about an organisation's ethical performance. Based on a systems theoretical definition of values, the case is made for a distinction of communication on values and value communication, the latter of which is defined as implicit form of communication. This distinction is illustrated by examples of personal and organisational value communication at Coca Cola France, Marriott Belgium, Accenture India, and two French retailers as well as a contrastive discussion of the CSR activities of Grünenthal $\mathrm{GmbH}$ and Coca Cola Hellenic Bottling. The findings suggest that research on business performance management by metaphor should be complemented with a focus on management by allusion, the latter of which could turn out to be effective to such extent that it finally calls for ethical concerns itself.
\end{abstract}

Keywords: value-based management; CSR performance; social systems theory; management by allusion; value communication; value semantics.

Reference to this paper should be made as follows: Roth, S. (2014) 'The things that go without saying: on performative differences between business value communication and communication on business values', Int. J. Business Performance Management, Vol. 15, No. 3, pp.175-191.

Biographical notes: Steffen Roth is Assistant Professor of Management and Organization at the ESC Rennes School of Business, France, and Visiting Professor at the International University of Rabat. He was awarded a $\mathrm{PhD}$ in Management from the Chemnitz University of Technology, and recently defended his second $\mathrm{PhD}$ thesis in Organisational Sociology to the University of Geneva. He held visiting professorships at the University of Cagliari, the Copenhagen Business School, and the Yerevan State University. His research fields include organisation theory, functional differentiation, ideation and crowdsourcing, and culturomics. 


\section{Value semantics as value communication? An introduction}

Articles on returns on value-based management or the link between business ethics and performance usually start from the observation that both organisational value communication and the corresponding academic discourses have been growing over the last years. CSR is on the hot list of recent trends in business performance research (Hopkins, 2003). Rumour of course has it that this ethical turn (Bartlett, 2003) might not be paralleled by complementary organisational value structures (Drucker, 1981). However, cases made for either position strongly rely on the analysis of value semantics in corporate documents and also on secondary data (von Groddeck, 2011a; Colle and Gonella, 2003). Although such a focus on value semantics is in line with common practice of research in business ethics and responsible management, in this article, analyses of value semantics explicitly expressed in interviews, websites, brochures or codes of conduct are not considered first choice if it comes to information about organisational value communication. Rather, we base on a system theoretical definition of value communication as an indirect or implicit form of communication. We thus challenge the idea that corporate values can be carefully designed by individuals, then disseminated and finally deciphered in terms of critical analyses of explicit value semantics (Willmott, 1993). We will make our case focussing on personal and organisational value communication in the context of internship experiences at Accenture India, Coca Cola France, Marriott Belgium, and two French retailers as well as a contrastive discussion the CSR activities of Grünenthal GmbH and Coca Cola Hellenic Bottling Company. Asking for the things that go without saying in these contexts, the article addresses the question as to whether an increase in the use of value semantics actually is an appropriate indicator for an increasing value orientation, or rather for the opposite. In the end, future research is invited to find out about whether only persons or also organisations actually do understand (other) organisations in terms of organisational value communication.

\section{Value communication as form and as a topic of communication: a theory statement}

Unlike the larger part of scholars in sociology or business ethics, Niklas Luhmann emphasises that values cannot guide decisions. Rather, Luhmann refers to von Foerster's (1992, p.14) insight, "only those questions that are in principle undecidable, we can decide", to stress that "decisions are always and only due when values pose conflicting demands (because if not, the decision would already be decided)" [Luhmann, (2008), p.29]. This idea becomes even more comprehensible if we reconsider value conflicts from the perspective of functional differentiation.

\footnotetext{
"In many fields, society has involved itself in its function systems in the mode of second-order observation, and has made itself dependent on this mode for achieving integration. The use of second-order observation has decisive consequences for moral communication. It now serves as a vehicle for observing morally oriented communication and destroys, with or without intention, the immediacy of moral evidence.” [Luhmann, (1992), p.1006]
} 
Moral communication can hence be observed in terms of its relevance for function systems such as the political system, the economy, science, art, or religion. ${ }^{1}$ In doing so, we find that - unlike in the Medieval - "(n)owadays, morals have no specific reference to a subsystem, e.g. knowledge (sciences), faith (religion) or power (politics). Therefore morals belong to the environment of all subsystems of the society, morals are equidistant to every sub-system. The code of morals and the code of the subsystems are not congruent" [Dallmann, (1998), p.89]. This higher amorality (Luhmann, 1991) of the function systems and their codes is evident if we exemplarily consider that there is no sense in moralising payments per se, for there is hardly a reason for defining payments as always good or non-payments as always bad, or vice versa. Moreover, every claim that a prayer is essentially better than a payment would be considered contestable, today. If taken for granted, however, such moral claims would make the decisions involved redundant. Moral communication and decision-making are therefore mutually exclusive.

Recent systems theoretical research ventures in value communication (von Groddeck, 2011a, 2011b), however, tended to base their discussion on the relationship of organisation and values on the weaker argument that values represent very abstract semantics and therefore are not able to guide actions or decisions:

\footnotetext{
“One should not stop at Luhmann's rather sceptical diagnosis of the potential of value communication. This is because one cannot ignore the fact that value semantics - even if they do not necessarily deliver the desired effect of controlling action - are empirically observable elements of organisational practice” [von Groddeck, (2011b), p.73]
}

In stating this, two important decisions are made. First, value communication is equated with value semantics and, second, it is claimed that value communications are elements of organisational systems. If we recall that, in social systems theory, organisations are as systems of decision communication [cf. von Groddeck, (2011b), p.71], however, then there is no way of making the second claim, because the only elements a system of decision can be made of are decisions. While this concern may seem hair-splitting, together with the equation of value communication and value semantics it results in empirical problems that become manifest in the attempt to analyse how and why "certain forms of value communication stabilise in organisations" [von Groddeck, (2011b), p.74], own emphasise). Such an attempt to find out how and why value communication stabilises in decision communications misses the point that organisations neither consist of humans, motivations, machines, or factory buildings [Baecker, (2006), p.112] nor of value communication. Rather, organisations 'consist of decisions' [Nassehi, (2005), p.186]. Value communication therefore neither takes place in organisations nor can be implemented within [as suggest by Schnebel and Bienert (2004)], but can only be attributed to organisations.

Moreover, Luhmann and Fuchs (1988) explicitly stress the implicit nature of value communication. "The concept of value denotes preferences the validity of which can safely be assumed in social communication without having to face disagreement" [cf. Luhmann, (2008), p.32]. Values are therefore valid only if they can be imputed in communication rather than directly expressed: 


\begin{abstract}
"Apparently, the most conspicuous characteristic of values is that they can be communicated inconspicuously. Corresponding to their presumed absolute validity, values are implied as allusions in social communication. (...) While communication itself focuses on issues that can be negotiated and disagreed upon, values remain latent in communication. Values are reproduced and stabilized through indirect communication.” [Luhmann and Fuchs, (1988), p.32f]
\end{abstract}

Values therefore literally are the things that go without saying. This also means that if values are explicitly addressed, if we, for example, need to take up the cause of peace, solidarity, or liberty, then these values are already contested, just because they obviously do not go without saying and therefore are no longer values.

The recent rise of explicit corporate communication on values is therefore hardly an indicator for a rise of value communication. In this sense, analyses of "written organizational documents like homepages or glossy brochures performed by this author" [von Groddeck, (2011b), p.75] would not lead to a better understanding of organisational value communication. Indeed, if companies explicitly promised to create value for everybody, to assume responsibility, or to live values, then this can be interpreted as an increased organisational awareness of the social environment. However, the fact that these organisations seem to have understood what its environment considers desired organisational behaviour and now demonstratively mirror these expectations on their brochures and websites has nothing to do with organisational value communication. Rather, we could assume that, at least in some cases, there is a systemic discrepancy between the officially listed value semantics and an organisation's value communication; in other words, we could assume that deviations from the exhibited value semantics do not only occur because "it is difficult for an organization to live up to all expectations of what the organization is supposed to do" [von Groddeck, (2011b), p.76], but also because organisations learn to use value semantics as moral shields and explore the new options that emerge behind them.

Against this background, we emphasise the distinction of social structures and semantics (Stäheli, 1997, 1998, 2000, 2010) not only because it guides the larger part of the few system theoretical empirical research ventures, but also because it helps to achieve a better picture of the difference between value as form or as a topic of communication, respectively. This difference is important in order to recall the fact that, like all systems, semantics are differences that make a difference (Bateson, 1972). The difference value semantics make, as compared to 'mere' value communication, is as important as the statement, "I am the winner", in the context of a game, whose rules are well know to everybody. In this example, this - unsportsmanlike - stating of the self-evident clearly indicates that the self-evident is considered not self-evident. In this sense, in the following, we suggest distinguishing value communication as social structure from communication on values in terms of value semantics. In concrete terms, we will focus on the question as to which differences the difference of value communication and communication on values makes in a number of different organisational contexts. In doing so, we will also present organisational settings where value communication was understood despite, or rather because of, the absence of value semantics. 


\title{
3 Personal observations of value communication without value semantics in an organisational context: insider views of Accenture India, Coca Cola France, Marriott Belgium, and two French retailers
}

The following statements refer to cases where value communication operated without any reference to value semantics. The statements represent personal experiences reported within essays on the distinction of value communication and communication on values in an organisational context written by international Master's and Programme Grande École students at the ESC Rennes School of Business. Case studies are used for a broad scope of purposes (Merriam, 1998). In the present case, the presented data has an illustrative rather than a revealing character. Consequently, there is hardly any issue with whether the students told a 'true story' or invented sometimes for the sake of a good mark. Rather, the essays show that the distinction of value communication and communication can be applied by students and leads to surprising observations. In this context, a French student reported her experiences during an internship in a Paris department store:

\begin{abstract}
"We were two students of E.S.C Rennes School of Business to do our professional experience in this department store. We were working in the beauty area and we had the same manager. We were sales advisors and the tasks, which were written on our internship agreement, were similar. After just two weeks, the manager's attitude towards each of us was significantly different. In my case, she gave me special assignments, like the elaboration of a sales promotion action plan or the sales promotion schedule. I was also in charge of the writing of the in-house newsletters of the store. In order to perform these new responsibilities, the manager allocated me time outside the sales area, as well as, space (a desk). Moreover, she trained me in order to well understand and be able to achieve each of my new tasks. She gave me regular feedbacks and she was very supportive during this tree-month internship. She was very comforting by expressing her satisfaction related to my work. When I met her, she was always smiling, her voice was calm and her face 'opened and relaxed'. Furthermore, she gave me the opportunity to attend the management committee and she introduced me to the other managers as well as the Director. When she was talking with her colleagues, she used to make a lot of compliments about my work, my motivation, and my engagement. Finally, at the end of my internship, she rewarded me with luxury beauty products.
\end{abstract}

Quite the opposite, she ignored the other student of E.S.C Rennes School of Business. She stayed on the sales area during all her internship long and she wasn't included in any project. When our manager talked to her, she was much colder, and, sometimes, she didn't even say 'hello' to her when she met her on the sales area.

This short narrative of my personal experience illustrates the idea of esteem communication in an organizational context. The manager didn't have to say that she preferred one of us, it was obvious.”

In this report, examples of the use of value semantics (appraisals, feedbacks, etc.) are still mixed with examples of value communication (amount of time and resources spent on the preferred intern), which becomes even more obvious if compared with the report of an Indian student, who shared her previous work experience as a technical consultant for Accenture India: 
"My supervisor was known to be very brilliant and particular about work. His style of motivation was to assign more difficult tasks one after the other. He would never congratulated his team for good work, but if he assigned projects full of risks, which required very high technical skills, this showed his confidence in the team to take on the situation and also appreciation for the previous ones completed. This always amazed me how he kept his team motivated and high performing even without using words (verbal or written).”

In a few words, the student describes how her manager used value communication instead of value semantics to provide feedback on job performance and how such a form of communication kept a team motivated.

A French student, who worked as intern in the HR department of Coca Cola France makes another case for a (self-) management by value communication that manages without value semantics:

\begin{abstract}
"My team was used to move a lot, in order to recruit in many departments. To these businesses travel, we have the choice to go by subway or by cab, then by plane or by train. In a normal time, everybody used to travel first class, to take a cab, etc. But this time, Coca-Cola Entreprises wasn't in a comfortable place; the business wasn't so good, so that a restructuration plan was discussed. So everybody paid attention to participate at the collective effort and try to not overspend, by taken the subway and not a cab for instance. But one of my colleagues paid not attention, and continued to spend as if nothing. It took a few weeks to everybody to consider this behavior inappropriate, but no one said anything. In fact, top management gave no order, so we had nothing to blame (specially me, I was only an intern). A few weeks after, my colleague ended up understanding that his behavior wasn't the right behavior to adopt in this situation.”
\end{abstract}

Here the student reflects on how the explicit communication of the restructuration plan created an implicit imperative to cut personal expenses, which went without saying for all team members except for one. Again, without saying, the compliant team members agreed on the inopportuneness of the deviant member's behaviour, which was finally understood by this member.

A French student with work experience as an intern in the HR department of Marriott Belgium gives an idea of how the concepts of value communication and management style are interlinked:

"The behavior and the attitudes of the Director of Human Resources of the hotel, herself, expressed quite some values by itself. As an example, she always arrived late at work compared to the other employees of the department, even if she was the manager. It was quite surprising at the beginning, I thought she might have had a hitch or an imperative. Instead, I learned that she used to go to the swimming-pool every morning and took the habit to postpone her hour of arrival. It took only a few days until I realized everybody's' feeling that her behavior was inappropriate and unfair. Moreover, she wasn't present at the staff party. As the Director of Human Resources (and hence one of the managers of the hotel), her absence was widely noticed and disapproved. She communicated a feeling of disesteem and unrespect towards the employees of the hotel. I also noticed this feeling towards her during lunch time. Indeed, she always sat at the company's canteen with managers or the director of the hotel. She extremely rarely talked to simple chambermaids.” 
“Marriott group conveys the value to 'put people first'. As J.W. Marriott said, 'if we take care of our employees, they will take care of our customers and they will come back ${ }^{2}$. This means that, around the globe, they offer their employees fair treatment, respect, and opportunities for personal and professional growth. In regards to the DHR's behavior, we can't say that she does live the values of the group. Nevertheless, she has been working within Marriott for five years.”

In the student's interpretation, the director's behaviour was understood as an implicit way of signalling that she considers herself a cut above the rest. This particular form of value communication again was considered an element of a management style that is not in line with the organisations communication on management values. Finally, the experiences of a French intern as a department manager of a French retailer point in similar direction:

\begin{abstract}
"In this firm, the hierarchical gap between employees and managers is quickly recognizable, even if one of the major company's aspects is to develop a trustful relationship between both sides. (...) The gap between employees and their manager is implicit, but obvious. Indeed, a French habit is to give a kiss on a cheek to say hello or goodbye to each other (women with men or women with other women). This tradition is used in every organization and it is an unsaid process to establish which role you are playing in the company. For example, we can notice several kind of situation according to your job: As a store director, you will shake hands, whoever (women or men) you will meet at work. As an employee, you will kiss other employees and shake hands to your superiors. This habit is seen in every level of the organization: employees are kissing each other and shaking hands to department managers, department managers are kissing each other and shaking hands to sector managers. And so on. This tacit and automatically process is used to emphasize hierarchical role. Then, the concept of trustful relationship is quite distorted because of the feeling of belonging to specific groups. According to my personal experience, I was sometimes confused. At that time, in this company, I was a trainee as a department manager. Normally, I should shake hands to employees, and kissing on cheeks department managers. But, because of my trainee status, employees were not considering me as a real manager, and some department managers wanted to keep a distance with me, shaking my hand. Sometimes, this French custom can create an unease situation, where both parties are not clear about the role the other is playing. Then, both actions can be disorganized: for instance, one person is holding out his/her hand to be shaken whereas the other is holding out his/her cheek to be kissed".
\end{abstract}

Here we are presented an instructive example of how the observation of value communication can help to uncover a certain clash between an organisation's preferred value semantics (trustful relationships) and the culture of value communication that condensates along the organisational structures. What is more, the present case illustrates the fact that, even if a form of communication is implicit, value communication features all the issues of double contingency commonly associated with the more explicit forms of communication.

The reading of these statements suggests that research focused on value semantics risks missing the point value communication is all about. Where would, for example, the Director of Human Resources in the Marriott case have put her cross at the seven-point Likert scale used on items like, "My personal values are generally compatible with the values of the organization" used (Posner and Schmidt, 1993) and recently reused (Posner, 2010) in research on the congruency of individual and organisational value systems? Maybe she would have highly agreed with the statement. Would the deviant team member in the Coca Cola case have answered that he was unclear about his 
organisation's values? Maybe not, because he felt he was perfectly in line with his organisation's value semantics, while his colleagues had already observed that he was missing a decisive shift of organisational value communication before he finally realigned with the changed situation.

\section{Organisational value communication with(out) value semantics: reading the case of the Grünenthal GmbH against the CSR performance of the Coca Cola Hellenic Bottling S.A.}

The following case illustrates how value communication cannot only be observed with regard to organisational structures, but also with regard to an organisation's relationship to its environment.

Looking at a particularly instructive history of organisation (Coleman, 1973a, 1973b), we find that the formation of modern organisation took place in a medium of values: Trusts owed their existence to attempts to protect the values of their members and their name to the value the members relied on to achieve it. Ever since, the shared-value-strategy has been understood as value communication - be it as disregard for the King, betrayal of the common good, undermining of the civil society, or an act of emancipation - and was soon copied by groups of persons interested in cultivating academic, legal, or sportive values, as well.

Looking at organisational value communication from this angle suggests distinguishing between ascribed and self-observed organisational value communication, just because the tone of the observed value communication might differ depending on whether it is observed by a competing organisation, a third party, or the organisation itself. If we furthermore recall that organisations are considered systems of decision communication, then we find again that there is no value communication in organisations. Rather, decision systems can be observed against a horizon of alternative values. Observers might then find that particular organisations tend to make decisions in a way that seems to refer to particular values more often than to other values. As we can easily imagine, however, different observers might identify quite different resonances between a given organisational structure and the great horizon of values because neither the most basic nor the most complex decision programs make decisions between values, but between decisions.

If we are now looking for an example of organisational value communication, i.e., value communication that can be plausibly attributed to an organisation and only this organisation, then we focus on a case where organisational value communication is observed by the organisation, and where this observation is communicated in terms of value communication itself.

\subsection{The case of Grünenthal GmbH: a socially responsible organisation with a bad image}

Between 1957 and 1961, German drug-maker Grünenthal GmbH distributed the still infamous tranquilliser, Thalidomide (Contergan). Thalidomide led to serious birth deformations when taken by pregnant women. Grünenthal received more than 1,600 insistent warnings throughout the year of 1961. Even more, the company never denied that it was perfectly aware of the drug's negative impact as of November 16, 
1961. Nonetheless, the drug was still distributed until November 26, 1961, which is the day after the publication of a relevant article in the German newspaper, Welt am Sonntag. By this date, a total number of at least 5,000 children had been born with serious birth deformations, not to mention an indefinable number of prenatal deaths.

The criminal case against the company was closed after 283 days in court in 1970. Eight months afore, Grünenthal and the parents of those injured had signed an extra-judicial agreement: The company paid a lump sum of 100 million DM, which both led to the establishment of a Disabled Children's Relief Foundation and freed Grünenthal from any further obligations.

Grünenthal's crisis management is still notorious even though the company has continued to volunteer financial support even after the first mandatory payment. Criticism was particularly stated in that it was not until 2007 that the Grünenthal Group started to establish personal contact with the victims and had never before 'personally' apologised for what had occurred. Today, the company considers the Thalidomide crisis as part of both its history and its present image. A link to a separate space exclusively devoted to Thalidomide (Grünenthal, 2013a) is just one click away from the corporate homepage (http://www.grunenthal.com, link history) and leads directly to a speech on the occasion of the inauguration of Thalidomide-Memorial held by the CEO in August 2012. This particular speech is a formidable example of an organisational approach to value semantics: A leading representative of the victims is addressed as brave and committed. Furthermore, the Thalidomide crisis is referred to as a tragedy, and the company's willingness to act responsible, to maintain engaged in the recently started open dialog, and to take care for the future lives of the victims is emphasised. In doing so, the organisation uses value semantics to respond to what it considers the values of the victims and the larger audience. If the company finally 'feels' the need to apologise "for the fact that we have not found the way to you from person to person for almost 50 years", then the artificial character of the entire constellation becomes even more evident: As a matter of logics, organisations cannot meet persons from person to person. Communicated by an organisation, all the willing value semantics, therefore, are, and can be, nothing more than the inaugurated memorial, which the CEO himself calls a symbol. Looking for the organisation's value communication rather than for value semantics in an organisational context, however, another document strikes our attention. Contrasting the emotional words of the speech, The Thalidomide chronology (Grünenthal, 2013b) is a table, in the form of which the company tells its version of the Thalidomide crisis, and which is remarkable in many regards (cf. Table 1, Annex).

The table contains hardly any reference to persons and not a single personal reference to members of Grünenthal. Rather, the organisation refers to further organisations as well to a number of function systems and the interplay between these. Finally, the table does not contain any value semantics and is nonetheless full of value communication, which is already indicated by the present paragraph. Actually, Grünenthal prefers organisations to persons. The only persons that are mentioned in the list are the two physicians, who first discovered the destructive effects of Thalidomide as well as a third physician to whom the drug owes a second pro-bono career as anti-leprosy treatment. Grünenthal members are kept out of the storyline of fire, which clearly indicates that the company is loyal to its members. The mentioning of the drugs second pro-bono career indicates not only that Grünenthal did not make money at all costs, but also that the company isloyal to its projects. 
As to organisations, Grünenthal refers to the Federal Republic of Germany, (indirectly) the Land court of Aachen, ${ }^{3}$ the Disabled Children's Relief Foundation, the World Health Organization, leprosy hospitals, the German Federal Association of Thalidomide Victims, and finally the absence of the Federal Institute for Drugs and Medical Devices. Furthermore, the German government is also mentioned not only as a cofounder and donator of the Disabled Children's Relief Foundation, but also in the sense that the missing German Drug Law was considered a pending governmental homework ever since Germany signed the Treaty of Rome in 1957. In terms of function systems, references to the health system, the legal system, science, the economy and the political system are dominant on the list.

Using the material presented on the list, Thalidomide reads as the story of a scientific effort that was intended to promote health and was turned into an economic product too early because the post-war political system(s) had not yet established appropriate legal frameworks for the interplay of science, medicine and the economy in the testing of new drugs. The company's own test procedures therefore had been in line with the current laws of the time. Actually, Grünenthal (2013b) had been rather eager to comply with the law: "Grünenthal (...) applies for prescription-only status for thalidomide in May 1961". Therefore, if the outcome of legal processes results in a legal problem, this is not supposed to be considered a legal problem of a pharmaceutical business, but rather a political problem of lawmakers. For the company, this interpretation is supported by the fact that the company has never been sentenced. Nonetheless, it did all it could to avoid further harm for both itself and the victims. As a business organisation, the only thing it could do was give money, which it went on doing even after its legal obligation to do so had ended.

With particular focus on the first and last entry of the table, the story can be summarised as follows: The political system made a mistake, ${ }^{4}$ which is why an economic organisation found itself in severe legal trouble and lost a lot of money, ${ }^{5}$ even though, or rather, because it displayed more corporate responsibility than it was forced to do.

\subsection{The background-case of Coca Cola Hellenic Bottling Company S.A: good reputation despite, or because of, a strategic CSR performance}

Coca Cola Hellenic Bottling Company S.A. is the second-largest Coca-Cola anchor bottler worldwide. The company belongs to the Dow Jones Sustainability Index and therefore is considered a responsible firm (López et al., 2007). In its Social Responsibility Report 2011 (Coca Cola Hellenic Bottling Company, 2011), the company lists consumer health, water stewardship, energy and climate change, packaging and recycling, employee development, supplier engagement, and community involvement as major fields of its CSR strategy. According to the then Public Affairs and Communication Manager of Coca Cola Hellenic Bottling Company Armenia, ${ }^{6}$ the focus of activities is clearly on the first two fields because the company decided to concentrate on CSR activities with a potential return on investment. Healthy consumers and clean water are considered key to the business. The company therefore invests in anti-diabetes and water treatment programs. Further activities involve energy saving, recycling, and accident avoidance measures. 


\subsection{Discussion}

Grünenthal obviously represents an excellent negative example of what is today considered competence in corporate communication on values, which is most clear with regard to the fact that the company waited several decades before personally addressing the victims and asking their forgiveness. The question, however, is why the company's speechlessness has been commonly understood as a sign of one of the most technocratic, heartless, and amoral forms of crisis management recorded in the German economic history and not as a sign of shock and helplessness in the face of a crisis that shook the company to the core of its values. Should we not rather take into consideration that an organisation with lower moral standards might have found it easier to strategically use value semantics than an organisation with higher standards? Speechlessness therefore could also be interpreted as an indicator for a deeply rooted, however, now deeply disturbed value system. In this sense, reading the case of Grünenthal's value communication against the CSR strategy of Coca Cola's Hellenic anchor bottler, the intellectual tension is in the fact that the latter isconsidered socially responsible, while hardly anybody would consider Grünenthal an example of an ethical firm. Obviously, the bottler is more competent in the use of value semantics and proud to draw the reader's attention to the fact that "the importance that we attach to sustainability at all levels of our business was acknowledged by the listing of Coca-Cola Hellenic for the fourth successive year in the Dow Jones Sustainability Indexes (World and STOXX)" (Coca Cola Hellenic Bottling Company, 2011) in 2011. When reading in between the lines of the company's communication on its values, however, the focus of its CSR activities could also be understood as a cynical message. In fact, the idea that the company claims to be socially responsible while obviously being interested in hardly more than maintaining the resources it needs to keep on making money could also be interpreted as a cynical approach to its environment.

\section{Value communication, management by allusion and business performance: an outlook}

If we ask the question as to why an organisation that aligns its eloquent CSR activities according to their anticipated return on investment is considered an ethical organisation, while an organisation that volunteers money in order to repair moral damage is suspected of amorality, then we do not want to take side with either of the companies. Rather, we used the examples of Grünenthal GmbH and Coca Cola Hellenic Bottling Company S.A. in order to stress the importance of the distinction between value communication and values as topics of communication as well as the broader perspective on value issues this distinction allows for.

The personal cases of value communication in an organisational context presented before the case studies also demonstrate that it makes sense to mind that explicit talk on values must not be mixed up with value communication, the latter of which is implicit by nature. If value communication rather than value semantics are observed as management tools, however, than we find that persons tend to translate decision communication into value communication, and that these translation processes open up spaces for both research agendas and management strategies. As indicated most clearly by example of the implicit feedback strategy in the case of Accenture India, value communication in a 
management context is understood by reading in between the lines of decisions rather than through sophisticated analyses of manifest value semantics. Just to quote a final, maybe rather unconventional, example of corporate value communication, the fact that Singapore's international multi-purpose port operator, Jurong Port Company (2013), and the Chinese exporter of general merchandise, Zhe Jiang Sunfine Industrial Company (2013), use the same value semantics on their websites is maybe the best proof that understanding value communication is not about the analysis of value semantics at all. If it were, we would be struck by the fact that two companies that operate in both different countries and different industries share exactly the same values. In this case, however, we would rather tend to assume that one of the companies copied the value semantics of the other. The value communication understood if value semantics are just copied and pasted is clearly that the copying company does not give much about values. In fact, the analysis of further cases of copy and paste-values does not only represent an independent research venture (Roth, 2013), but also draws our attention to maybe less obvious, however, still hardly more creative paraphrasing strategies along fashionable keywords, such as sustainability, responsibility, or innovation openness.

The presented considerations therefore did not stop at the mere observation of incongruences between espoused and enacted values (Beyer and Lutze, 1993), intended and realised strategies or images (Mintzberg, 1978; de Roeck et al., 2013), talk and practice (Clegg et al., 2007), instrumental and genuine CSR (Kemper and Martin, 2010; El Abboubi and Nicolopoulou, 2012), self- or societal interest (Lin-Hi and Blumberg, 2012), or between the is and the ought of value-based management (de Graaf, 2001). All these approaches to the moral dimension of management and organisation are most instructive, however, they all feature a moral dimension themselves in terms of an obvious bias to one of the two sides of the key distinction they promote, which usually also assumed to be closer to some concept of "the real culture of organizations" [Willmott, (2003), p.79; own emphasis]. In this article, however, we have made our case without taking sides for either of the two forms of communication. We considered neither value communication nor communication on values closer to any kind of organisational reality than the other. The only claim we made was that communication on values does not provide information about organisational value communication. Assessments of an organisation's ethical or CSR performance are therefore advised to not to focus on organisational value semantics. Future research in organisational value communication might therefore be willing to consider a fundamental realignment of the relationship of organisations and values, maybe by starting with bringing the observer of organisational value communication back into its own observation. In fact, it might be exciting to find that values are not possessed and value communication not performed by organisations, but rather that value communication refers to the second partner it takes to tango. The question then would be whether we can imagine something like inter-organisational value communication, or whether organisational value communication is rather exclusively about the personalisation of a form of social systems that can address both persons and values only in terms of topics of decision communications.

The modest idea that values are things that go without saying proofs far reaching with regard to future research ventures focused on the assessment of an organisations ethical performance. In fact, we can now challenge the popular idea that an increase in the use of value semantics actually is an appropriate indicator for an increasing value orientation. The question then is why organisations seem to have an increasing need for explicitly expressing what should go without saying. Be it considered self-defence or a 
selling-strategy, the problem with this semantic over-justification is that it raises exactly the kind of doubts it tries to overcome and leads organisations into a vicious circle out of which analyses of value semantics cannot guide the way. Managers thus could end up finding that their task is less about a management by metaphor (Lapp and Carr, 2008; Alvesson, 2012), but rather about a management by allusion. In fact, management by allusion could turn out to be effective to such extend that it calls for ethical concerns itself.

\section{References}

Alvesson, M. (2012) Understanding Organizational Culture, SAGE Publications Limited, London.

Baecker, D. (2006) 'The form of the firm', Organization, Vol. 13, No. 1, pp.109-142.

Bartlett, D. (2003) 'Management and business ethics: a critique and integration of ethical decision-making models', British Journal of Management, Vol. 14, No. 3, pp.223-235.

Bateson, G. (1972) Steps to an Ecology of Mind: Collected Essays in Anthropology, Psychiatry, Evolution, and Epistemology, University of Chicago Press, Chicago.

Beyer, J. and Lutze, S. (1993) 'The ethical nexus: organizations, values and decision-making', in Conrad, C. (Ed.): The Ethical Nexus, Ablex, NJ.

Clegg, S., Kornberger, M. and Rhodes, C. (2007) 'Business ethics as practice', British Journal of Management, Vol. 18, No. 2, pp.107-122, DOI: 10.1111/j.1467-8551.2006.00493.x.

Coca Cola Hellenic Bottling Company (2011) Sustainable Values. Sustainable Living, Social Responsibility Report 2011, Athens.

Coleman, J.S. (1973a) 'Loss of power’, American Sociological Review, Vol. 38, No. 1, pp.1-17.

Coleman, J.S. (1973b) Power and the Structure of Society, Norton, New York.

Colle, S. and Gonella, C. (2003) 'Corporate social responsibility: the need for an integrated management framework', International Journal of Business Performance Management, Vol. 5, No. 2, pp.199-212.

Dallmann, H.U. (1998) 'Niklas Luhmann's systems theory as a challenge for ethics', Ethical Theory and Moral Practice, Vol. 1, No. 1, pp.85-102.

de Graaf, G. (2001) 'Discourse theory and business ethics. The case of bankers' conceptualizations of customers', Journal of Business Ethics, Vol. 31, No. 4, pp.299-319, DOI: 10.1023/A: 1010772910497.

de Roeck, K., Maon, F. and Lejeune, C. (2013) 'Taking up the challenge of corporate branding: an integrative framework’, European Management Review, Vol. 10, No. 3, pp.137-151.

Drucker, P.F. (1981) 'Ethical chic’, Forbes, Vol. 128, No. 6, pp.160-173.

El Abboubi, M. and Nicolopoulou, K. (2012) 'International social-related accountability standards: using ANT towards a multi-stakeholder analysis’, M@n@gement, Vol. 15, No. 4, pp.392-414.

Grünenthal (2013a) About Thalidomide [online] http://www.contergan.grunenthal.info/grtctg/GRT-CTG/Stellungnahme/Rede_anlaesslich_Einweihung_des_ConterganDenkmals/224600963.jsp (accessed 27 November 2013).

Grünenthal (2013b) Thalidomide Chronology [online] http://www.contergan.grunenthal.info/grtctg/GRT-CTG/Die_Fakten/Chronologie/152700079.jsp (accessed 27 November 2013).

Hopkins, M. (2003) 'The business case for CSR: where are we?’, International Journal of Business Performance Management, Vol. 5, No. 2, pp.125-140.

Jurong Port Company (2013) Our Core Values [online] http://www.jp.com.sg/JurongPort/corevalues/ (accessed 27 November 2013).

Kemper, A. and Martin, R.L. (2010) 'After the fall: the global financial crisis as a test of corporate social responsibility theories', European Management Review, Vol. 7, No. 4, pp.229-239, DOI: 10.1057/emr.2010.18. 
Lapp, C.A. and Carr, A.N. (2008) 'Coaching can be storyselling: creating change through crises of confidence', Journal of Organizational Change Management, Vol. 21, No. 5, pp.532-559.

Lin-Hi, N. and Blumberg, I. (2012) 'The link between self- and societal interests in theory and practice’, European Management Review, Vol. 9, No. 1, pp.19-30.

López, M.V., Garcia, A. and Rodriguez, L. (2007) 'Sustainable development and corporate performance: a study based on the Dow Jones sustainability index', Journal of Business Ethics, Vol. 75, No. 3, pp.285-300, DOI: 10.1007/s10551-006-9253-8.

Luhmann, N. (1991) 'Paradigm lost: on the ethical reflection of morality speech on the occasion of the award of the Hegel Prize 1988', Thesis Eleven, Vol. 29, No. 1, pp.82-94.

Luhmann, N. (1992) 'Code of the moral’, The Cardozo Law Review, Vol. 14, No. 1, pp.995-1009.

Luhmann, N. (2008) 'Are there still indispensable norms in our society?’, Soziale Systeme, Vol. 14, No. 1, pp.18-37.

Luhmann, N. and Fuchs, S. (1988) 'Tautology and paradox in the self-descriptions of modern society', Sociological Theory, Vol. 6, No. 1, pp.21-37.

Merriam, S.B. (1998) Qualitative Research and Case Study Applications in Education, Revised and Expanded from Case Study Research in Education, Jossey-Bass Publishers, San Francisco.

Mintzberg, H. (1978) 'Patterns in strategy formation', Management Science, Vol. 24, No. 9, pp.934-948.

Nassehi, A. (2005) 'Organizations as decision machines: Niklas Luhmann's theory of organized social systems', The Sociological Review, Vol. 53, No. 1, pp.178-191.

Posner, B.Z. (2010) 'Another look at the impact of personal and organizational values congruency', Journal of Business Ethics, Vol. 97, No. 4, pp.535-541, DOI: 10.1007/s10551-010-0530-1.

Posner, B.Z. and Schmidt, W.H. (1993) 'Values congruence and differences between the interplay of personal and organizational value systems', Journal of Business Ethics, Vol. 12, No. 5, pp.341-347.

Roth, S. (2013) 'Common values? Fifty-two cases of value semantics copying on corporate websites', Human Systems Management, Vol. 32, No. 4, pp.249-265, DOI: 10.3233/HSM130801.

Roth, S. (2014) 'Coining societies. An inter-functional comparative analysis of the euro', Innovation: The European Journal of Social Science Research, DOI: 10.1080/ 13511610.2013.864229 (forthcoming).

Schnebel, E. and Bienert, M.A. (2004) 'Implementing ethics in business organizations', Journal of Business Ethics, Vol. 53, Nos. 1-2, pp.203-211.

Stäheli, U. (1997) 'Exorcising the 'popular' seriously: Luhmann's concept of semantics 1', International Review of Sociology, Vol. 7, No. 1, pp.127-145, DOI: 10.1080/03906701.1997. 9971228.

Stäheli, U. (1998) 'Zum Verhältnis von Sozialstruktur und Semantik', Soziale Systeme, Vol. 4, No. 2, pp.315-340.

Stäheli, U. (2000) Sinnzusammenbrüche, Velbrück, Weilerswist.

Stäheli, U. (2010) 'Dekonstruktive Systemtheorie - Analytische Perspektiven', in John, R., Henkel, A. and Rückert-John, J. (Eds.): Die Methodologien des Systems, pp.225-239, Wiesbaden, VS Verlag für Sozialwissenschaften.

von Foerster, H. (1992) 'Ethics and second-order cybernetics', Cybernetics and Human Knowing, Vol. 1, No. 1, pp.9-19.

von Groddeck, V. (2011a) 'The function of dysfunctions: the paradox of value-based leadership communication', European Journal of International Management, Vol. 5, No. 1, pp.30-47.

von Groddeck, V. (2011b) 'Rethinking the role of value communication in business corporations from a sociological perspective - why organisations need value-based semantics to cope with societal and organisational fuzziness', Journal of Business Ethics, Vol. 100, No. 1, pp.69-84, DOI: 10.1007/s10551-011-0769-1. 
Willmott, H. (1993) 'Strength is ignorance; slavery is freedom: managing culture in modern organizations', Journal of Management Studies, Vol. 30, No. 4, pp.515-552.

Willmott, H. (2003) 'Renewing strength: corporate culture revisited’, M@n@gement, Vol. 6, No. 3, pp.73-87.

Zhe Jiang Sunfine Industrial Company (2013) Entreprise Values [online] http://cnsunfine.com/ merchandise/about.asp (accessed 27 November 2013).

\section{Notes}

1 A comprehensive list of the function systems and their codes is presented in Roth (2014).

2 http://www.marriott.com/culture-and-values/core-values.mi (accessed 27 November 2013).

3 Due to the insufficient size of the courtrooms in Aachen, the venue of the court proceedings was a Casino in Alsdorf.

4 The first entry reads as follows: "There are no regulations in the Federal Republic of Germany governing the development, production or sale of medicines. There is no German Drug Law/Medicines Act and no Federal Institute for Drugs and Medical Devices (BfArM) or similar agency” (Grünenthal, 2013b).

5 The last entry reads as follows: "About $€ 500$ million has been paid to thalidomide victims to date" (Grünenthal, 2013b).

6 The mentioned conversion took place in the context of an Open Society Institute and Soros Foundations Network meeting of academic fellows in 2011. We did not intend to obtain the cited information.

\section{Annex}

Table 1 The Thalidomide chronology

\begin{tabular}{|c|c|}
\hline Until the mid-1950s & $\begin{array}{l}\text { There are no regulations in the Federal Republic of Germany governing } \\
\text { the development, production or sale of medicines. There is no German } \\
\text { Drug Law/Medicines Act and no Federal Institute for Drugs and } \\
\text { Medical Devices (BfArM) or similar agency. }\end{array}$ \\
\hline 1954 & $\begin{array}{l}\text { Grünenthal obtains a patent for thalidomide, the active drug substance in } \\
\text { the product called Contergan in Germany. }\end{array}$ \\
\hline \multirow[t]{2}{*}{1 October 1957} & $\begin{array}{l}\text { Thalidomide is launched on the West German market and sold under the } \\
\text { brand name Contergan. }\end{array}$ \\
\hline & $\begin{array}{l}\text { Until withdrawn, thalidomide is sold in a total of } 46 \text { countries under } \\
\text { various brand names. }\end{array}$ \\
\hline October 1959 & $\begin{array}{l}\text { First reports suggesting thalidomide might cause nerve damage in the } \\
\text { hands and feet (polyneuropathy). }\end{array}$ \\
\hline
\end{tabular}

Source: http://www.contergan.grunenthal.info/grt-ctg/GRTCTG/Die_Fakten/Chronologie/152700079.jsp (accessed 27 November 2013) 
Table 1 The Thalidomide chronology (continued)

1961 Grünenthal amends the package leaflet disclosing the side effect and
applies for prescription-only status for thalidomide in May 1961 on
account of the polyneuropathy.

16 November 1961

A Hamburg-based paediatrician, Dr. Widukind Lenz, voices the first suspicion that deformities in unborn children may be associated with thalidomide.

An Australian gynaecologist, Dr. William G. McBride, expresses the same suspicion at approximately the same time.

27 November 1961 Grünenthal withdraws thalidomide from the West German market.

27 May 1968

April 1970

18 December 1970 Scientists succeed for the first time in demonstrating teratogenicity of the active drug substance thalidomide in animal experiments in white New Zealand rabbits.

An Israeli physician, Jacob Sheskin, discovers thalidomide’s effectiveness in treating leprosy.

Legal proceedings are instigated against nine Grünenthal executives and research employees in Alsdorf near Aachen.

While criminal proceedings are still ongoing, Grünenthal begins negotiations with the joint plaintiffs and voluntarily pledges to pay DM 100 million to thalidomide victims.

The case is discontinued against the defendants.

The West German government enacts a law setting up a public foundation called Disabled Children's Relief Foundation.

The government paid DM 100 million into the Foundation and Grünenthal contributed DM 114 million. Grünenthal is held harmless and indemnified against any other claims

Prior to the mid-1980s A number of legal challenges are brought unsuccessfully challenging the Foundation as the sole means of obtaining compensation.

1990s

Scientists discover that thalidomide has anti-inflammatory effects on the immune system and inhibits the formation of new blood vessels. The drug is used to treat severe illnesses including AIDS and cancer.

1998-present Other companies distribute thalidomide, ensuring the availability of other sources to meet the medical need.

June 2003

Grünenthal stops supplying thalidomide. At the request of the World Health Organisation (WHO), Grünenthal had been supplying thalidomide tablets since the 1970s to support leprosy hospitals in the treatment of a leprosy complication called ENL reaction. Strict conditions applied in order to prevent thalidomide from being given to pregnant women. Grünenthal supplied the drug on a not-for-profit basis.

December 2005 As thalidomide victims are now adults, the Disabled Children's Relief Foundation is renamed Contergan Foundation for People with Disabilities.

December 2007 First meeting between Grünenthal and representatives of the German Federal Association of Thalidomide Victims.

Source: http://www.contergan.grunenthal.info/grt-ctg/GRT-

CTG/Die_Fakten/Chronologie/152700079.jsp

(accessed 27 November 2013) 
Table 1 The Thalidomide chronology (continued)

February 2008

May 2008

May 2009

July 2009

Grünenthal works with the German government and the German Federal Association of Thalidomide Victims towards a collaborative solution to improve the situation of thalidomide victims.

Grünenthal announces a voluntary payment of $€ 50$ million into the existing Contergan foundation (Conterganstiftung für behinderte Menschen), based in Germany. With the move, Grünenthal aims to double the Contergan Foundation's capital stock to enable the onceannual payment of an additional personal sum to thalidomide victims. The German Federal Association of Contergan Victims sees the model as another step in the right direction.

Revision of the Contergan Foundation Act creates the legal basis enabling Grünenthal GmbH to pay the voluntary sum of $€ 50$ million into the foundation to improve the financial situation of thalidomide victims.

Grünenthal transfers the voluntary sum of $€ 50$ million to the Contergan Foundation.

The Foundation now has a capital stock of $€ 100$ million for annual special payments to thalidomide victims. As a result, in addition to a monthly pension of up to $€ 1116$, individuals damaged by thalidomide stand to receive annual payments of $€ 460$ to $€ 3680$ for the next 25 years. The pension and special payments are provided regardless of any other social benefits thalidomide victims receive. The top-up on payments puts them in a significantly more secure financial position than before in Germany and in comparison with other countries.

Grünenthal aspires to continue engaging in constructive dialogue with thalidomide victim.

About $€ 500$ million has been paid to thalidomide victims to date.

Source: http://www.contergan.grunenthal.info/grt-ctg/GRTCTG/Die_Fakten/Chronologie/152700079.jsp

(accessed 27 November 2013) 